\title{
Pengaruh Teknik Relaksasi Benson Terhadap Kualitas Tidur pada Lanjut Usia
}

\section{The Effect of the Benson Relaxation Technique on Sleep Quality in the Elderly}

\author{
${ }^{1}$ Rahmat Hidayat, ${ }^{2}$ Haeril Amir,
}

1,2Jurusan S1 Keperawatan, Fakultas Kesehatan Masyarakat, Universitas Muslim Indonesia, Makassar

\begin{tabular}{|c|c|}
\hline A R T I C L E I N F O & A B S T R A C T \\
\hline & Benson Relaxation is a technique for reducing pain, overcoming sleep disorders and dealing \\
\hline Article history : & with anxiety. The developmental stage of the elderly is characterized by the loss of a lot of \\
\hline Received 2021-June-10 & body cells and a decrease in the metabolism of body cells which causes a decrease in body \\
\hline Received in revised form 2021-June-17 & function and changes in body composition as well as a decrease in strength and health. One \\
\hline Accepted 2021-June-18 & $\begin{array}{l}\text { of the complaints that are felt related to sleep is difficulty sleeping, often waking up during } \\
\text { the night and feeling unrefreshed when awakened from sleep. This research is a type of }\end{array}$ \\
\hline Keywords : & quantitative research with a quasi-experimental design. This research was conducted using \\
\hline Elderly & the Nonequivalent Control Group Design. The total population is 100 people. Sampling in this \\
\hline Sleep Quality & study is a non probability sampling. In this design, there are two groups of research subjects \\
\hline Benson Relaxation & $\begin{array}{l}\text { as many as } 10 \text { people for the intervention group and } 10 \text { people for the control group. The } \\
\text { intervention given was benson relaxation which was carried out for } 2 \text { weeks with a frequency }\end{array}$ \\
\hline Kata Kunci : & of 2 times a day with a duration of 30 minutes. The data analysis used was bivariate analysis \\
\hline Lanjut Usia & with Paired Sample T test and Independent T-Test. The results of the Independent T-Test \\
\hline Kualitas Tidur & analysis showed that the value of $p=0.000(0.000<0.05)$. Thus there is an effect of giving \\
\hline Relaksasi Benson & $\begin{array}{l}\text { benson relaxation on the sleep quality of the elderly at PSTW Gau Mabaji Gowa. From this } \\
\text { research, it is hoped that the Benson relaxation technique can be a non-pharmacological }\end{array}$ \\
\hline & ding nursing care to elderly patients who experience sleep disorders. \\
\hline
\end{tabular}

Rahmat Hidayat

Email : rahmat.hidayat@umi.ac.id

\begin{abstract}
A B S T R A K
Relaksasi Benson merupakan salah satu teknik untuk mengurangi nyeri, mengatasi gangguan tidur dan mengatasi kecemasan. Tahap perkembangan lanjut usia dicirikan dengan kehilangan banyak sel tubuh dan penurunan metabolisme sel sel tubuh yang menyebabkan penurunan fungsi tubuh dan perubahan komposisi tubuh serta terjadi penurunan kekuatan dan kesehatan. Salah satu keluhan yang dirasakan terkait tidur adalah kesulitan untuk tidur, sering terbangun saat tidur malam dan merasa tidak s egar saat terbangun dari tidur. Penelitian ini adalah jenis penelitian kuantitatif dengan desain quasi eksperimen. Penelitian ini di lakukan dengan menggunakan Nonequivalent Control Group Design. Jumlah populasi sebanyak 100 orang. Pengambilan sampel pada penelitian ini adalah non probability sampling. Dalam desain ini terdapat dua kelompok subjek penelitian yaitu sebanyak 10 orang untuk kelompok intervensi dan 10 orang kelompok kontrol. Intervensi yang diberikan yaitu relaksasi benson yang dilakukan selama 2 minggu dengan frekuensi 2 kali dalam sehari berdurasi 30 menit. Analisa data yang digunakan adalah analisa bivariat dengan uji Paired Sample T test dan Independent T-Test. Hasil analisis Independent T-Test diperoleh nilai $p=0,000(0,000<0,05)$. Dengan demikian ada pengaruh pemberian relaksasi benson terhadap kualitas tidur lanjut usia di PSTW Gau Mabaji Gowa. Dari penelitian ini diharapkan teknik relaksasi benson dapat menjadi terapi non farmakologi dalam pemberian asuhan keperawatan pada pasien lanjut usia yang mengalami gangguan tidur.
\end{abstract}

\section{PENDAHULUAN}

Manusia dalam rentang hidupnya memiliki 8 tahap perkembangan dan tahap yang terakhir adalah lanjut usia. Lanjut usia itu sendiri merupakan metode perkembangan manusia yang dimulai pada usia 60 tahun atau 70 tahun dan berakhir sampai kematian. Tahap perkembangan lanjut usia dicirikan dengan kehilangan banyak sel tubuh dan penurunan metabolisme sel-sel tubuh yang menyebabkan penurunan fungsi tubuh dan perubahan komposisi tubuh serta terjadi penurunan kekuatan dan Kesehatan (1). Salah satu keluhan yang dirasakan terkait tidur adalah kesulitan untuk tidur, sering terbangun saat tidur malam dan merasa tidak segar saat terbangun dari tidur (2).

Cuellar dalam menemukan bahwa lebih dari 50\% lanjut usia (65 tahun keatas) melaporkan memiliki gangguan tidur (2). Lanjut usia memiliki kualitas tidur yang buruk, yaitu sebanyak 77,7\% dari 301 responden, karena seiring bertambahnya usia, semakin menurun persentasi tidur REM (Rapid Eye Movement) dan SWS (Slow Wave Sleep) pada tidur lanjut usia. Berdasarkan Badan Pusat Statistik, pada tahun 2010 jumlah lansia di Sulawesi Selatan adalah 721.353 jiwa yaitu 9,19\% dari total

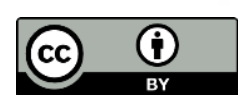


jumlah penduduk Sulawesi Selatan. Jumlah lansia di kota Makassar sebanyak 79.581 jiwa sedangkan di Kabupaten Gowa dengan jumlah lansia sebanyak 49.030 jiwa (3).

Kualitas tidur adalah kepuasan seseorang terhadap tidur yang dapat ditentukan oleh bagaimana seseorang mempersiapkan pola tidur pada malam hari, seperti kedalaman tidur, kemampuan untuk tetap tertidur, kemudahan untuk tertidur tanpa bantuan medis. Kualitas tidur yang baik dapat memberikan perasaan tenang di pagi hari, perasaan energik, dan tidak mengeluh gangguan tidur. Dengan kata lain, memiliki kualitas tidur baik sangat penting dan vital untuk hidup sehat semua orang (4).

Masalah tidur dan masalah kualitas hidup yang rendah berkontribusi terhadap masalah kesehatan mental dan fisik. Gangguan tidur dan kurang tidur adalah sebuah masalah kesehatan baik fisik dan mental yang dapat berpengaruh terhadap perawatan kesehatan. Masalah tidur telah diketahui bagi perilaku profesional selama beberapa dekade, tetapi pasien belum mendapatkan diagnosis dan pengobatan layak (5).

Dampak yang terjadi apabila seseorang tidak mampu mencukupi kebutuhan tidurnya, adalah perubahan kepribadian dan perilaku seperti: agresif, menarik diri, atau depresi, rasa capai meningkat, gangguan persepsi, halusinasi pendengaran atau pandangan, bingung dan disorientasi terhadap tempat dan waktu, koordinasi menurun serta bicara tidak jelas, mudah tersinggung dan tidak rileks (6).

Salah satu upaya yang dapat dilakukan untuk mengatasi masalah gangguan pemenuhan kebutuhan istirahat tidur adalah dengan menggunakan tehnik relaksasi Benson. Benson memperkenalkan tehnik relaksasi yaitu suatu tehnik pengobatan untuk menghilangkan nyeri, insomnia dan kecemasan(7). Berdasarkan hal tersebut di atas maka penulis tertarik untuk melakukan penelitian tentang Pengaruh Teknik Relaksasi Benson Terhadap Pemenuhan Kebutuhan Tidur Pada Lansia.

\section{METODE}

Rancangan penelitian yang digunakan pada penelitian ini adalah jenis penelitian kuantitatif dengan desain quasi eksperimental. Desain penelitian ini dilakukan dengan menggunakan Nonequivalent Control Group Design, yaitu Dalam desain ini terdapat dua kelompok, kelompok pertama diberi perlakuan dan kelompok yang lain tidak, tetapi sebelumnya di ukur atau di test terlebih dahulu (pre test) selanjutnya setelah perlakuan atau tanpa perlakuan kelompok studi di ukur atau di test kembali (posttest) (8).Penelitian ini akan dilaksanakan di panti Sosial Tresna Werdha Gau Mabaji Gowa. Populasi dalam penelitian ini adalah semua lansia di Panti Sosial Tresna Werdha Gau Mabaji Gowa dengan jumlah 100 orang terdiri dari 61 orang perempuan dan 39 orang laki-laki.Besar sampel dalam penelitian ini adalah 20 orang yang dibagi menjadi 2 kelompok yaitu 10 orang untuk kelompok intervensi dan 10 orang untuk kelompok kontrol. Pengambilan sampel dalam penelitian ini harus memenuhi kriteria.

\section{HASIL DAN PEMBAHASAN}

\section{Karakteristik Responden}

Didapatkan bahwa sebanyak $0(0 \%)$ yang berumur lansia awal, sedangkan dari 2 responden yang berumur lansia akhir ada sebanyak $1(10 \%)$ responden pada kelompok intervensi dan $1(10 \%)$ responden pada kelompok kontrol dan dari 18 responden yang berumur manula ada sebanyak 9 (90\%) responden pada kelompok intervensi dan 9 (90\%) responden pada kelompok control, Sedangkan dari 9 responden yang berjenis kelamin laki laki ada 4 (40\%) responden pada kelompok intervensi dan ada sebanyak $5(50 \%)$ responden pada kelompok kontrol. Serta dari 16 responden yang lama di panti antara 0-10 tahun ada $8(80 \%)$ responden pada kelompok intervensi serta ada $8(80 \%)$ responden pada kelompok kontrol, dari 3 responden yang lama di panti antara 11-20 tahun ada 2 (20\%) responden pada kelompok intervensi serta ada $1(10 \%)$ responden pada kelompok kontrol, dan dari 1 responden yang lama di panti antara 21-30 tahun ada $0(0 \%)$ responden pada kelompok intervensi serta ada $1(10 \%)$ responden pada kelompok control.

\section{Analisis Univariat}

Tabel 1

Distribusi Responden Berdasarkan umur, jenis kelamin, dan lama dipanti pada lanjut usia di Panti Sosial Tresna Werda Gau Mabaji Gowa Tahun 2016

\begin{tabular}{|c|c|c|c|c|c|c|c|}
\hline \multirow{2}{*}{\multicolumn{2}{|c|}{ Karakteristik Responden }} & \multicolumn{2}{|c|}{ Kelompok Intervensi } & \multicolumn{2}{|c|}{ Kelompok Kontrol } & \multicolumn{2}{|c|}{ Total } \\
\hline & & $\mathrm{n}$ & $\%$ & $\mathrm{n}$ & $\%$ & $\mathrm{n}$ & $\%$ \\
\hline \multirow{3}{*}{ Umur } & Lansia Awal & 0 & 0 & 0 & 0 & 0 & 0 \\
\hline & Lansia Akhir & 1 & 10 & 1 & 10 & 2 & 10 \\
\hline & Manula & 9 & 90 & 9 & 90 & 18 & 90 \\
\hline
\end{tabular}

This is an open-access article under the CC BY 4.0 International License

(c) An Idea Health Journal (2021) 


\begin{tabular}{llllllll}
\hline \multirow{2}{*}{ Jenis Kelamin } & Laki-laki & 4 & 40 & 5 & 50 & 9 & 45 \\
& Perempua & 6 & 60 & 5 & 50 & 80 & 11 \\
\hline \multirow{3}{*}{ Lama Dipanti } & 0-10 Tahun & 8 & 80 & 8 & 10 & 3 & 80 \\
& 11-20 Tahun & 2 & 20 & 1 & 10 & 1 & 15 \\
& 21-30 Tahun & 0 & 0 & 1 & 5 \\
\hline
\end{tabular}

Sumber : Data Primer

Hasil penelitian menunjukkan bahwa sebagian besar responden yang mengalami gangguan kualitas tidur adalah umur manula yaitu sebanyak 90\%. Sedangkan umur Lansia Akhir yaitu sebanyak 10\%. Serta tidak ada responden dengan umur lansia awal. Manula dalam penelitian ini lebih dominan mengalami gangguan tidur, Hasil penelitian menunjukkan bahwa sebagian besar responden yang mengalami gangguan tidur adalah perempuan yaitu sebanyak 55\%. Sedangkan laki laki yang mengalami gangguan tidur adalah $45 \%$. Perempuan dalam penelitian ini lebih dominan mengalami gangguan tidur. Hasil penelitian menunjukkan bahwa sebagian besar responden yang mengalami gangguan tidur adalah responden yang tinggal dipanti antara 0 - 10 tahun yaitu sebanyak $80 \%$. Sedangkan responden yang mengalami gangguan tidur yang tinggal dipanti antara 11 - 20 tahun yaitu sebanyak 15\%. Serta responden yang mengalami gangguan tidur yang tinggal dipanti antara 21 - 30 tahun yaitu sebanyak $5 \%$.

Tabel 2

Distribusi Kualitas Tidur Sebelum dan Sesudah Pada lanjut usia di Panti Sosial Tresna Werdha Gau Mabaji Gowa Tahun 2016

\begin{tabular}{clccccc}
\hline \multicolumn{1}{c}{ Variabel } & \multicolumn{1}{c}{ Kelompok } & $\mathrm{n}$ & Mean & SD & Min-Mak & $95 \%$ CI \\
\hline \multirow{2}{*}{ Kualitas Tidur Pre } & Intervensi & 10 & 6,36 & 0,853 & $5-8$ & $5,75-6,97$ \\
& Kontrol & 10 & 7,28 & 1,505 & $6-10$ & $6,20-8,36$ \\
\hline \multirow{2}{*}{ Kualitas Tidur Post } & Intervensi & 10 & 2,51 & 1,065 & $1-4$ & $1,75-3,27$ \\
& Kontrol & 10 & 6,67 & 2,717 & $2-12$ & $4,73-8,61$ \\
\hline
\end{tabular}

Sumber : Data Primer

Hasil penelitian menunjukkan rata-rata kualitas tidur responden sebelum perlakuan pada kelompok intervensi adalah 6,36 dengan nilai kualitas tidur terendah adalah 5 dan nilai kualitas tidur tertinggi adalah 8. Sedangkan rata-rata kualitas tidur responden sebelum perlakuan pada kelompok kontrol adalah 7,28 dengan nilai kualitas tidur terendah adalah 6 dan nilai kualitas tidur tertinggi adalah 10. Hasil penelitian menunjukkan rata-rata kualitas tidur responden setelah perlakuan pada kelompok intervensi adalah 2,51 dengan nilai kualitas tidur terendah adalah 1 dan nilai kualitas tidur tertinggi adalah 4. Sedangkan ratarata kualitas tidur responden setelah perlakuan pada kelompok kontrol adalah 6,67 dengan nilai kualitas tidur terendah adalah 2 dan nilai kualitas tidur tertinggi adalah 12 .

Tabel 3

Analisis Rata-rata Skor Kualitas Tidur Kelompok Intervensi Sebelum dan Sesudah Dilakukan Latihan Relaksasi Benson di Panti Sosial Tresna

Werdha Gau Mabaji Gowa Tahun 2016

\begin{tabular}{|c|c|c|c|c|c|}
\hline Variabel & Kelompok & $\mathrm{n}$ & Mean & SD & $P$ Value \\
\hline \multirow{2}{*}{ Kualitas Tidur } & Pre & 10 & 6,36 & 0,853 & 0,000 \\
\hline & Post & 10 & 2,52 & 1,065 & \\
\hline
\end{tabular}

Sumber : Data Primer

Tabel 4

Analisis Rata-rata Skor Kualitas Tidur Kelompok Kontrol Sebelum dan Sesudah Dilakukan Latihan Relaksasi Benson di Panti Sosial Tresna Werdha Gau Mabaji GowaTahun 2016

\begin{tabular}{|c|c|c|c|c|c|}
\hline Variabel & Kelompok & $\mathrm{n}$ & Mean & SD & $P$ Value \\
\hline \multirow{2}{*}{ Kualitas Tidur } & Pre & 10 & 7,28 & 1,505 & 0,345 \\
\hline & Post & 10 & 6,67 & 2,717 & \\
\hline
\end{tabular}

Sumber : Data Primer 
Tabel 5

Analisis Perbedaan Skor Kualitas Tidur Sesudah Dilakukan Latihan Relaksasi Benson Pada Kelompok Kontrol dan Intervensi di Panti Sosial Tresna Werdha Gau Mabaji Gowa Tahun 2016

\begin{tabular}{cccccc}
\hline Variabel & Kelompok & $\mathrm{n}$ & Mean & SD & $P$ Value \\
\hline \multirow{2}{*}{ Kualitas Tidur } & Intervensi Kontrol & 10 & 2,51 & 1,065 & 0,000 \\
& & 10 & 6,67 & 2,717 & \\
\hline
\end{tabular}

\section{Sumber : Data Primer}

Hasil analisis menunjukkan rata-rata skor kualitas tidur kelompok intervensi sebelum dilakukan latihan relaksasi benson adalah 6,36 ( $\mathrm{SD}=0,853)$, hasil penelitian ini yaitu skor kualitas tidur mengalami penurunan rata-rata skor kualitas tidur sesudah dilakukan latihan relaksasi benson selama dua minggu adalah $2,51(\mathrm{SD}=1,065)$. Hasil uji statistik didapatkan nilai $p=0,000$ kurang dari nilai $\alpha=0,05$, sehingga dapat disimpulkan bahwa ada perbedaan yang signifikan antara kualitas tidur sebelum dan sesudah dilakukan latihan relaksasi otot progresif pada kelompok intervensi. Hasil penelitian ini sejalan dengan penelitian yang dilakukan oleh Aemilianus yang menunjukkan bahwa ada peningktan kualitas tidur setelah dilakukan teknik relaksasi benson dengan nilai probabilitas $p=0,000$ (7).

Hasil penelitian ini membuktikan bahwa terdapat pengaruh yang bermakna perbedaan rata-rata kualitas tidur sebelum dan setelah mendapatkan relaksasi benson pada kelompok intervensi. sehingga dapat disimpulkan bahwa latihan benson dapat meningkatkan kualitas tidur lansia. Sedangkan hasil penelitian pada kelompok kontrol tidak menunjukkan adanya perbedaan yang signifikan antara kualitas tidur sebelum dan sesudah latihan benson dengan nilai rata-rata sebelum perlakuan adalah 7,28 $(\mathrm{SD}=1,505)$ menjadi 6,67 dengan $(\mathrm{SD}=2.717)$, hasil penelitain ini didapakan bahwa kualitas tidur klien yang tidak mendapatkan perlakuan latihan relaksasi benson tidak mengalami peningkatan kualitas tidur yang signifikan. Hasil uji statistik didapakan nilai ( $p$ value $=0,356$ lebih besar dari nilai $\alpha=0,05$ ). Peneliti berasumsi bahwa tidak adanya pengaruh sebelum dan sesudah perlakuakn pada kelompok kontrol karena klien tidak mendapatkan perlakuan berupa latihan relaksasi benson, sehingga klien tidak mendapatkan perasaan relaks. Sehingga diharapkan dengan semakin cepat mencapai kondisi relaks maka seseorang akan lebih cepat untuk memasuki kondisi tidur yang berarti akan dapat mengatasi gangguan tidur yang dialami.

Hasil uji statistik menunjukkan bahwa ada perbedaan secara signifikan skor rata-rata kualitas tidur setelah perlakuan pada kelompok intervensi dan kelompok kontrol dengan nilai $\mathrm{p}=0.000$. Hal ini menunjukkan bahwa perlakuan yang dilakukan berupa latihan relaksasi benson pada klien gangguan tidur memiliki pengaruh yang positif pada peningkatan kualiatas tidur klien. Purwanto menyatakan latihan relaksasi dapat digunakan untuk memasuki kondisi tidur karena dengan mengendorkan otot secara sengaja akan membentuk suasana tenang dan santai (9). Suasana ini diperlukan untuk mencapai kondisi gelombang alpha yaitu suatu keadaan yang diperlukan seseorang untuk memasuki fase tidur awal.

Respon relaksasi yang melibatkan keyakinan yang dianut menurut Benson akan mempercepat terjadinya keadaan relaks, sehingga kombinasi respon relaksasi dengan melibatkan keyakinan akan melipatgandakan manfaat yang didapat dari respon relaksasi. Sehingga diharapkan dengan semakin cepat mencapai kondisi relaks maka seseorang akan lebih cepat untuk memasuki kondisi tidur yang berarti akan dapat mengatasi gangguan tidur yang dialami (10).

\section{KESIMPULAN}

Rata-rata kualitas tidur kelompok intervensi sebelum latihan relaksasi benson adalah 6,36, sedangkan ratarata kualitas tidur pada kelompok kontrol sebelum latihan relaksasi benson adalah 7,28. Rata-rata kualitas tidur kelompok intervensi sesudah latihan relaksasi benson adalah 2,51. Sedangkan rata-rata kualitas tidur kelompok kontrol sesudah latihan relaksasi benson adalah 6,67. Terdapat perbedaan yang signifikan ratarata kualitas tidur klien lansia antara kelompok intervensi sebelum dan setelah di lakukan relaksasi benson $(p=0,000)$. Tidak terdapat perbedaan yang signifikan rata-rata kualitas tidur klien lansia pada kelompok kontrol sebelum dan sesudah dilakukan relaksasi otot progresif $(p=0,345)$. Ada rata-rata perbedaan skor yang signifikan antara kualitas tidur sebelum dan sesudah dilakukan latihan relaksasi benson pada kelompok intervensi dan kontrol $(p=0,000)$, sebaiknya Pelayanan keperawatan Menerapkan teknik relaksasi benson pada perawatan klien dengan gangguan tidur sesuai kriteria pasien terpilih (tanpa kontra indikasi) yang dilakukan minimal dua kali sehari pada siang dan sore hari. 


\section{UCAPAN TERIMA KASIH}

Terima kasih kepada semua pihak yang telah berkontribusi dalam penelitian ini baik yang secara langsung maupun tidak langsung.

\section{DAFTAR PUSTAKA}

1. Stockslager JL, Schaeffer L. Buku SakuAsuhanKeperawatan Geriatrik. 2th.Ed. Subekti. penerjemah NB, editor. Jakarta: EGC; 2008. 209 p.

2. Potter, Perry. Basic Nursing, 7th ed. 7th.Ed. Canada: Mosby; 2011.

3. BPS. Karakteristik Kependudukan. Sulawesi Selatan; 2010.

4. Potter, Perry, Anne. Fundamental of Nursing. Concepts, Process and Practice, 8th ed. Canada: MMosby; 2013.

5. Mollaoughu, Mukadder. Sleep in Patients with ESRD Undergoing Hemodialysis, Progress in Hemodialysis - From Emergent Biotechnology to Clinical Practice, Prof. Angelo Carpi (Ed.). 2011

6. Meida, Fitri Y. Gangguan Tidur Pada Lansia. 2016;Available from: https://www.google.co.id/url?q=https://stikeskabmalang.files.wordpress.com/2009/10/gangguan-tidurpada-lansia.doc\&sa=U\&ved=0ahUKEwiEwJewz9nLAhXDjo4KHSDhAGcQFggSMAA\&sig2=ZzRKtHAN44Miimw Q2dWXnA\&usg=AFQjCNGDOFhT c6cKPiTLm5ntRCmv8rsByg.doc

7. Mau, Aemilianus. Pengaruh Penerapan Teknik Relaksasi Benson terhadap Gangguan Tidur (Insomnia). [Internet].

8. Benson, Herbert. Respon Relaksasi: Teknik Meditasi Sederhana dan Untuk Mengatasi Tekanan Hidup (terjemahan). Bandung: Mizan; 2000. 